\title{
Microbial Analysis of Ragi Cake Base Stored at Room Temperature without Added Chemical Preservative
}

\author{
S.N. Chaudhari ${ }^{*}$, S.B. Palve ${ }^{2}$, K.R. Choudhari ${ }^{3}$, D.H. Pawar ${ }^{4}$ and S.S. Gaikwad ${ }^{4}$ \\ ${ }^{1}$ Department of Food Science and Technology, ${ }^{2}$ Department of Food Engineering, \\ ${ }^{3}$ Department of Food and Industrial Microbiology, K. K. Wagh College of Food Technology, \\ Nashik - 422003, Maharashtra, India \\ ${ }^{4}$ K. K. Wagh College of Food Technology, Nashik - 422003, Maharashtra, India \\ *Corresponding author
}

\begin{tabular}{|c|c|}
\hline \multicolumn{2}{|r|}{ A B S T R A C T } \\
\hline & \multirow{7}{*}{$\begin{array}{l}\text { Microbial analysis is essential part of food safety. In the present study ragi cake base was } \\
\text { analysed for the microbial tests. All samples were taken in triplicates. Specific media were } \\
\text { used for identification of different microbes (yeast, mould, bacteria). For the identification } \\
\text { and microbial analysis Total Plate Count (TPC), Potato Dextrose Agar (PDA) were used } \\
\text { and for confirmation of number of colonies. In this study, the cakebase samples were } \\
\text { prepared without added chemical preservative and stored at room temperature were used } \\
\text { for microbial analysis. Ragi cake was prepared with ragi flour and refined wheat flour in } \\
\text { proportion of } 50: 50 \text { and condensed milk, butter, baking powder, baking soda, aerated } \\
\text { water and cocoa powder. The microbiological quality of ragi cake base was monitored by } \\
\text { analyzing the total plate count (TPC) and yeast and mold count (Y\&M). Results obtained } \\
\text { in this study revealed that ragi cake base stored at room temperature spoiled about } 3.5 \\
\text { times faster than stored at chilled temperature. At room temperature storage, the cakes } \\
\text { become moldy on the } 8^{\text {th }} \text { day with the highest TPC of } 6.05 \text { log } 10 \text { CFU and Y\&M count of } \\
6.21 \log 10 \text { CFU. }\end{array}$} \\
\hline & \\
\hline $\begin{array}{l}\text { Ragi cake, Mould, } \\
\text { Yeast, Bakery } \\
\text { product, Microbial } \\
\text { analysis and TPC. }\end{array}$ & \\
\hline Article Info & \\
\hline $\begin{array}{l}\text { Accepted: } \\
26 \text { October } 2017\end{array}$ & \\
\hline Available Online: & \\
\hline & \\
\hline
\end{tabular}

\section{Introduction}

Baking industry is considered as one of the major segments of food processing in India. Baked products are gaining popularity because of their availability, ready to eat convenience and reasonable good shelf life and taste (Vijaykumar et al., 2013). Cake is the form of food that is usually sweet and often baked. It supplies body building protein, fats and carbohydrates. Cake is normally prepared with refined wheat flour, sweetening agent (sugar), binding agent, egg, fat and vanaspati, liquid flavor and some form of leavening agent such as yeast or baking powder (Salunke, 2015). Finger millet flour can be used to enrich the nutritional quality of cake. Finger millet (Eleusine coracana) also known as ragi, nachni or Nagli is one of the important millets in India. Finger millet is extensively grown on hilly areas and southern part of India and is widely consumed in the form of dumping by vast section of people. Finger millet is the rich source of Calcium (300-350mg\%), Phosphorus(283mg\%), Iron (3.9\%) (Swami and Swami, 2006). Nowadays, food safety issues are getting more stringent as it affects the safety and 
health of human. Present study focussed on the microbiological testing of food as it is also important to ensure safety of food.

According to Islam et al., (2013), food safety consists of three types of hazards which are microbiological, physical and chemical hazards. Thus, food safety is also the concept that food will not be injurious to the consumer at the point of consumption, when it is prepared and or eaten according to its intended use (International Organization for Standardization, 2005). However, microbiological hazards are the critical factors to affect the consumer due to the production of bacteria and toxin that may cause cases of food poisoning.

Ragi cake base is one type of ready-to-eat foods. However, it is categorized as a type of cake that provides an excellent growth medium for many kinds of microorganisms, as it provides rich nutrients for microorganisms, high in moisture content and has a neutral $\mathrm{pH}$ (Siriken et al., 2009). This type of ready to eat cake product is not shelf stable and pose a potential public health risk if subjected to temperature abuse at any stage of their production, storage, distribution and marketing as well as their production under unhygienic conditions.

In Gilbert et al., (2000) reported that unsatisfactory value for microbiological quality of various ready-to-eat foods were greater than $6 \log 10 \mathrm{CFU}$ for aerobic plate count while acceptable values are within 5 $\log 10 \mathrm{CFU}$ to $6 \log 10 \mathrm{CFU}$. The Institute of Food Science and Technology (IFST) has also drawn up the generalized microbiological specification for cakes and pastries, which stated the maximum acceptable levels of yeast is $5 \log 10 \mathrm{CFU}$ and moulds is $4 \log 10 \mathrm{CFU}$. Furthermore, according to Good Manufacturing Practice (GMP) guidelines indicates the level expected immediately following production of food, for cakes and pastries for Yeast and Moulds is $2 \log 10 \mathrm{CFU}$ (Carl, 2014). In addition, stated that the microbiological quality of ready-to-eat foods $\geq 5 \log 10 \mathrm{CFU}$ was considered unsatisfactory level for TPC while $<4 \log 10 \mathrm{CFU}$ was considered satisfactory level (Food Standards Australia New Zealand, 2015).

In addition, the storage temperature of ragi cakes at the end of food supply chain which are in the retail outlets become important as it may affect the microbiological stability of the cake. However, most cakes are normally laid out on shelves at room temperature rather than being stored in refrigerators.

Undesirable microbial growth in cakes and other bakery products may occur, resulting in spoilage especially when stored at room temperature (Jariyawaranugoon, 2013). In addition, some of the major contaminants present in the filled baked products are mold and yeast that contributed to the overall microbial load of the bakery products. These contaminants also play major role in the spoilage of the baked products due to inadequate preparatory steps like cooling, slicing and transport (Shahbaz, et al., 2013). Therefore, the aim of this research was to study the microbiological quality of ragi cake base stored at room temperature.

\section{Materials and Methods}

\section{Material}

The different types of raw material are used for the preparation of ragi cake base. Like (Ragi flour, refined wheat flour, condensed milk, cocoa powder, baking powder, baking soda, chocolate essence, butter) in which some raw material are having very low shelf life easily effect on microbial contamination. Therefore, needs the study of microbial analysis. 


\section{Methods}

\section{Microbiological method}

\section{Determination of total plate count}

The microbiological analysis was carried out according to (U.S. Food and Drug Administration, 2001). Total plate count (TPC) was determined at $0^{\text {th }}, 2^{\text {nd }}, 4^{\text {th }}, 6^{\text {th }}$ and $8^{\text {th }}$ days of storage at room temperature. Ragi cake base Sample $25 \mathrm{gm}$ was aseptically weighed and placed in a plastic bag. One gram of the ragi cake samples was obtained (using a sterile knife and wearing sterile disposable hand gloves) and transferred into 9 $\mathrm{ml}$ of distilled water in a glass beaker. The beaker was shaken thoroughly. Serial dilution of the solution was done by transferring $1 \mathrm{ml}$ into $9 \mathrm{ml}$ of distilled water upto $10^{-2}$ dilution. From each of the serially diluted samples $0.1 \mathrm{ml}$ was plated on Plate Count Agar plates. The plates were inverted and then incubated at $37 \pm 1^{\circ} \mathrm{C}$ for $48 \mathrm{hr}$ and colonies seen were counted. Number of CFU was counted and reported as log CFU/gm.

\section{Determination of yeast and mold count}

Yeast \& Mould counts were determined by spread plating method at $0^{\text {th }}, 2^{\text {nd }}, 4^{\text {th }}, 6^{\text {th }}$ and $8^{\text {th }}$ days of storage at room temperature (U.S. Food and Drug Administration, 2001). Sample $25 \mathrm{gm}$ was aseptically weighed and placed in a plastic bag. One gram of the ragi cake samples was obtained (using a sterile knife and wearing sterile disposable hand gloves) and transferred into $9 \mathrm{ml}$ of distilled water in a glass beaker. The beaker was shaken thoroughly. Serial dilution of the solution was done by transferring $1 \mathrm{ml}$ into 9 $\mathrm{ml}$ of distilled water upto $10^{-2}$ dilution. From each of the serially diluted samples $0.1 \mathrm{ml}$ was inoculated over Potato Dextrose agar plates. These plates were incubated at $25^{\circ} \mathrm{C}$ for 5-7 days.

\section{Results and Discussion}

In this study, different duration of storage at room temperature was used for microbial observations. On the basis of observations of microbial growth whereby molds have started to grow on the $6^{\text {th }}$ day of storage, therefore the analysis was discontinued on day $8^{\text {th }}$ at room temperature storage. The ragi cake base stored at room temperature was seen to be moldy on the $8^{\text {th }}$ day of storage. Based on this study, TPC and Y\&M count increased during storage period of 8 days at room temperature. This happened because the room temperature $\left(25^{\circ} \mathrm{C} \pm 2^{\circ} \mathrm{C}\right)$ is the optimum temperature that allows growth of microorganism and this temperature also falls below the danger zone temperature which is $4.4-60^{\circ} \mathrm{C}$. Leaving food out too long at room temperature can cause bacteria to grow to dangerous levels that can cause illness because the bacteria grow most rapidly in danger zone temperature, which doubling in number in as little as 20 minutes (United States Department of Agriculture., Food Safety and Inspection Service, 2013.).

Furthermore, it is also due to the presence of oxygen which allows growth of aerobic microorganisms (Jariyawaranugoon, 2013). Another study showed that Y\&M started to grow on the $10^{\text {th }}$ day of cakes stored at ambient temperature (Khaki et al., 2012). Upon storage at room temperature, highest TPC was $6.05 \log 10 \mathrm{CFU}$ on the $8^{\text {th }}$ day of storage while yeast and mold were $6.21 \log 10$ CFU on the $8^{\text {th }}$ day of storage. Therefore, the results of the present study showed that the ragi cake base stored at room temperature might not be safe to consume on the $8^{\text {th }}$ day of storage onwards as the results of TPC and Y\&M were greater than the permitted level. 
Table.1 Total plate count at serial dilutions and at various time intervals

\begin{tabular}{|c|c|c|c|}
\hline Day & \multicolumn{3}{|c|}{ No of Colonies } \\
\hline & $\mathbf{1 0}^{\mathbf{0}}$ & $\mathbf{1 0}^{-\mathbf{1}}$ & $\mathbf{1 0}^{\mathbf{- 2}}$ \\
\hline $0^{\text {th }}$ & 0 & 0 & 0 \\
\hline $2^{\text {nd }}$ & 0 & 0 & 0 \\
\hline $4^{\text {th }}$ & 22 & 2 & 0 \\
\hline $6^{\text {th }}$ & 38 & 12 & 0 \\
\hline $8^{\text {th }}$ & 288 & 105 & 19 \\
\hline
\end{tabular}

Table.2 Pictures of total plate count

\begin{tabular}{|c|c|c|c|}
\hline Sr. No. & Day Number & Dilution factor & No. of Colonies \\
\hline 1. & $0^{\text {th }}$ day & $\begin{array}{l}10^{0}=0 \text { count } \\
10^{-1}=0 \text { count } \\
10^{-2}=0 \text { count }\end{array}$ & \\
\hline 2. & $2^{\text {nd }}$ day & $\begin{array}{l}10^{0}=0 \text { count } \\
10^{-1}=0 \text { count } \\
10^{-2}=0 \text { count }\end{array}$ & \\
\hline Sr. No. & Day Number & Dilution factor & No. of Colonies \\
\hline 3. & $4^{\text {th }}$ day & $\begin{array}{l}10^{0}=22 \text { count } \\
10^{-1}=2 \text { count } \\
10^{-2}=0 \text { count }\end{array}$ & \\
\hline
\end{tabular}




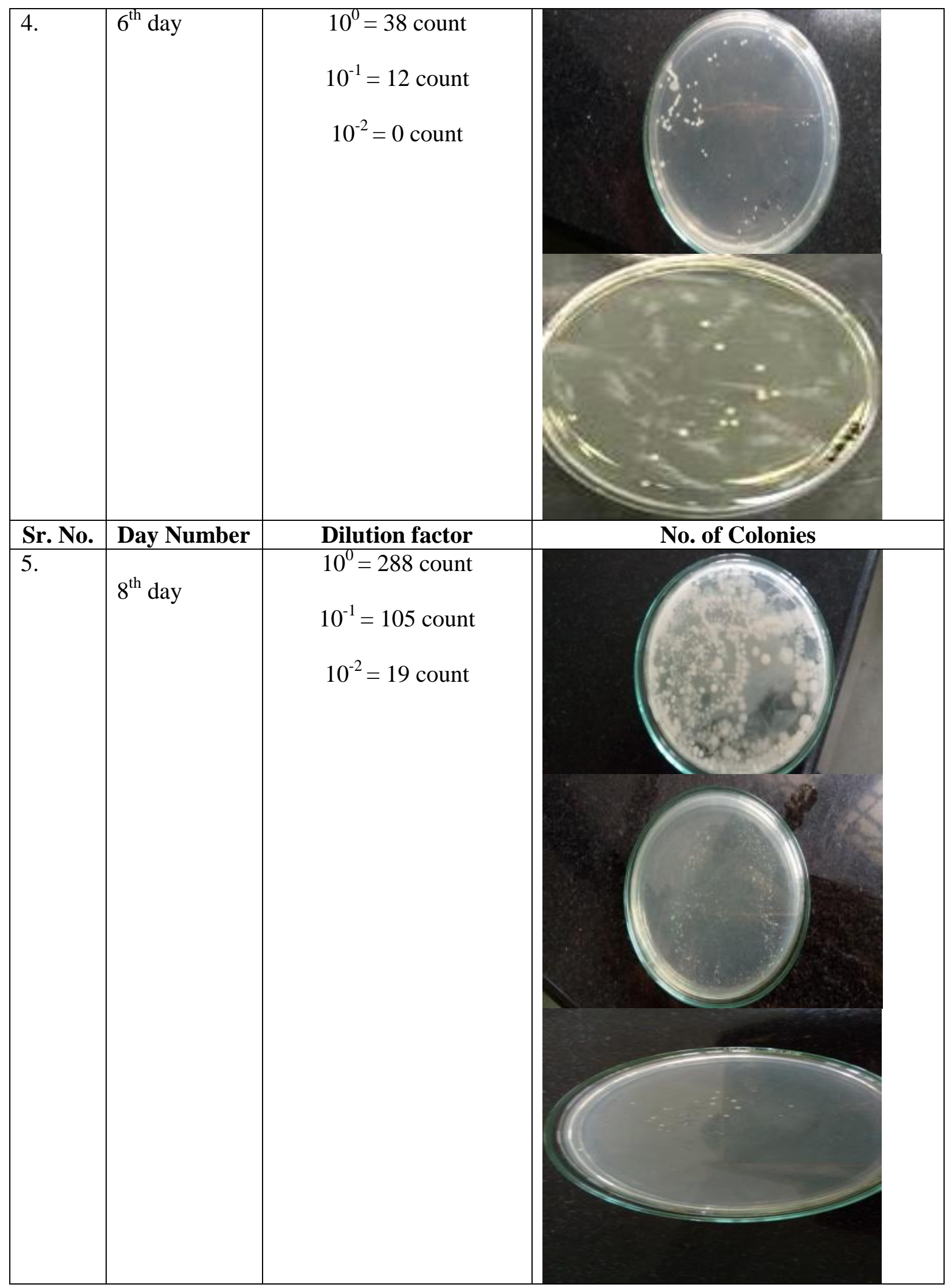


Table 1 gives details Total Plate Count of ragi cake base. Table depicts results about number of colonies at $0^{\text {th }}, 2^{\text {nd }}, 4^{\text {th }}, 6^{\text {th }}$ and $8^{\text {th }}$ day.

Table 2 gives details about number of count, day and respective pictorial count. Plates with nil (zero) colony count are not depicted in the table.

Ragi cake base was prepared with $50 \%$ Ragi flour and $50 \%$ refined flour and additional other ingredients like condensed milk, butter, baking powder, baking soda, cocoa powder and essence. The prepared ragi cake base didn't contained any chemical preservative and was stored at room temperature. The microbial analysis of the cake base determined by analysing Total Plate Count, Yeast and Mould count by recording the observations upto $10^{-2}$ dilutions. The microbial analysis of cake base was analysed at $0^{\text {th }}, 2^{\text {nd }}, 4^{\text {th }}, 6^{\text {th }}$ and $8^{\text {th }}$ day. The colony appeared from $4^{\text {th }}$ day of analysis. On $4^{\text {th }}$ day number of colony were 22 for $10^{\circ}$ dilution, on $6^{\text {th }}$ day 38 colony and $8^{\text {th }}$ day 288 colony respectively. By calculation the colony count was within the permissible limit. After $8^{\text {th }}$ day Yeast and mould growth was observed and sample was deteriorated. Thus, it was found that ragi cake base was spoiled at $8^{\text {th }}$ day of it's storage at room temperature.

\section{References}

Carl, A.B. (2014): Confectionery productsCakes and pastries. In Encyclopedia of Food Microbiology (Ed. C.A. Batt), Academic Press, Massachusetts 500502.

Food Standards Australia New Zealand, (2015): Standard 3.2.2: Food safety practices and general requirements. Retrieved from https://www.food standards.gov.au/publications/document s/3_2_2.pdf.
Gilbert, R.J., De Louvois J., Donovan T., Little C., Nye K., Ribeiro C.D., Richards J., Roberts D. and Bolton F.J., (2000): Guidelines for the Microbiological Quality of Some Ready-to-Eat Foods Sampled at the Point of Sale. Communicable Disease and Public Health/PHLS, 3(3), 163-167.

International Organization for Standardization, (2005): ISO 22000:2005, Food Safety Management Systems Requirements for any organisation in the food chain. Retrieved from https://www.iso.org/obp/ui/\#iso: std:iso:22000:ed-1:v1:en.

Islam, G.M.R. and Houque M.M., (2013): Food Safety Regulation in Bangladesh, Chemical Hazard and Some Perception to Overcome the Dilemma. International Food Research Journal, 20 (1), 47-58.

Jariyawaranugoon, U., (2013): Combined Effect of Honey and Oxygen Absorber Packaging on Storage Quality of Chocolate Sponge Cake. Journal of Food Science and Technology, 5 (3), 236-243.

Khaki, M., Sahari M. and Barzegar M., (2012): Evaluation of Antioxidant and Antimicrobial Effects of Chamomile (Matricaria Chamomilla L.)Essential Oil on Cake Shelf Life. Journal of Medicinal Plants, 11 (43), 9-18.

Salunke S. Jyoti (2015): Nutritional Analysis of Cake Formulated with Ragi Flour and Peanut Butter, International Journal of Innovations in Engineering and Technology (IJIET), 5(4): 294 -297.

Shahbaz, M., Hanif K., Masood S., Rashid A. A. and Bilal M., (2013): Microbiological Safety Concern of Filled Bakery Products in Lahore. Pakistan Journal of Food Science, 23 (1), 37-42.

Siriken, B., Cadirci O., Inat G. And Pamuk S., (2009): Microbiological Examination of 
Meatball, Cream Cake and Turkish Delight (Lokum). Journal of Animal and Veterinary Advances, 8 (10), 2049-2054.

Swami S.S., Swami S.B., (2006): Physical properties of finger millet (Eleusine coracana). International Journal of Agriculture Science, 3, 156-166.

United States Department of Agriculture's Food Safety and Inspection Service, 2013. Molds on food: Are they dangerous? Retrieved from http://www.fsis.usda.gov/wps/wcm/conn ect/a87cdc2c-6ddd-49fo-bdlf39308674 2e68/Molds_on_Food.pdf?MOD=AJPE RES.
U.S. Food and Drug Administration,(2001): Bacteriological analytical manual online. Retrieved http://www.911emg. com/Ref\%20Library\%20ERG/FDA\%20 Bacteriological\%20Analysis.pdf.

Chappalwar Vijayakumar, M., Peter Dayanand, Bobde H., John Steffi, M. (2013): Quality characteristics of cookies prepared from oats and finger millet based composite flour. International Journal of Engineering Science and Technology 3(4), 22503498.

\section{How to cite this article:}

Chaudhari, S.N., S.B. Palve, K.R. Choudhari, D.H. Pawar and Gaikwad, S.S. 2017. Microbial Analysis of Ragi Cake Base Stored at Room Temperature without Added Chemical Preservative. Int.J.Curr.Microbiol.App.Sci. 6(12): 3519-3525. doi: https://doi.org/10.20546/ijcmas.2017.612.409 